\title{
SUSCEPTIBILITY TO ANTIMICROBIAL AGENTS AND ANALYSIS OF PLASMIDS IN GENTAMICIN- AND METHICILLIN-RESISTANT STAPHYLOCOCCUS AUREUS FROM DUBLIN HOSPITALS
}

D. C. Coleman, H. Pomeroy, J. K. Estridge, C. T. Keane*, M. T. CAFFERKEY*, R. HONE $\dagger$ AND T. J. Foster

Department of Microbiology, Moyne Institute, Trinity College, Dublin 2, * Department of Clinical Microbiology, Trinity College, St James's Hospital, James's Street, Dublin 8, and $\dagger$ Department of Microbiology, The Mater Misericordiae Hospital, Dublin 9, Ireland

\begin{abstract}
SUmm AR Y. Methicillin- and gentamicin-resistant Staphylococcus aureus (MGRSA) strains isolated from Dublin Hospitals were classified into two groups (phenotypes). Phenotype-I strains expressed high level resistance to gentamicin and were susceptible to fusidic acid; strains resistant to tetracycline harboured a $3 \times 10^{6}-\mathrm{mol}$. wt plasmid. Strains in phenotype II usually expressed low level resistance to gentamicin, were resistant to fusidic acid and often harboured a $(22-24) \times 10^{6}-\mathrm{mol}$. wt plasmid that specified resistance to ethidium bromide, tetracycline, kanamycin, neomycin and trimethoprim, or to combinations of these markers. A few phenotype-II strains expressed higher levels of resistance to gentamicin and other aminoglycosides. All MGRSA strains carried a $21 \times 10^{6}$-mol. wt plasmid conferring resistance to penicillin, ethidium bromide, cadmium and mercury. Gentamicin resistance was invariably chromosomal and all strains carried chromosomal resistance to methicillin, erythromycin, streptomycin and spectinomycin.

Several methicillin-resistant $S$. aureus (MRSA) strains isolated before the emergence of gentamicin resistance harboured a $21 \times 10^{6}$-mol. wt penicillinase plasmid with the same restriction endonuclease profile as that from some MGRSA strains. Some MRSA strains carried other plasmids related to those found in MGRSA strains.
\end{abstract}

\section{INTRODUCTION}

Methicillin- and gentamicin-resistant strains of Staphylococcus aureus (MGRSA) have become an important cause of infection in Dublin hospitals (Hone et al., 1981; Cafferkey et al., 1983). These organisms express resistance to a wide range of antimicrobial agents. They belong to a limited number of phage types and many are untypable by standard typing phages (Cafferkey et al., 1983). Curing and transfer experiments have shown that they harbour plasmids encoding resistance to penicillin 
$\left(21 \times 10^{6}-\mathrm{mol}\right.$. wt plasmid) and tetracycline $\left(3 \times 10^{6}-\mathrm{mol}\right.$. wt or $24 \times 10^{6}-\mathrm{mol}$. wt plasmid) (Dowd et al., 1983). In this paper we report a retrospective analysis of MGRSA strains isolated between 1976 and 1984 and of a small number of methicillin-resistant (MRSA) strains isolated between 1970 and 1975 before the emergence of gentamicin resistance.

\section{MATERIALS AND METHODS}

Bacterial strains. The strains of $S$. aureus were clinical isolates obtained from the Federated Dublin Voluntary Hospitals, the Mater Misericordiae Hospital, Dublin and from Jervis Street Hospital, Dublin between 1970 and March 1984. S. aureus strain RN4220 Nov is a novobiocin-resistant mutant of strain RN4220, a restriction-deficient derivative of strain 8325-4 (Fairweather et al., 1983; Kreiswirth et al., 1983). Strains were stored in $40 \% \mathrm{v} / \mathrm{v}$ glycerol at $-20^{\circ} \mathrm{C}$.

Chemicals and antibiotics. Chemicals were obtained from Sigma (Poole, Dorset) or BDH Chemicals Ltd (Poole, Dorset). Antibiotics and other inhibitors were obtained as follows: benzyl penicillin, gentian violet, cetyltrimethyl ammonium bromide, ethidium bromide, gentamicin, kanamycin, tetracycline, neomycin and acriflavine were purchased from Sigma. Chlorhexidine was from Imperial Chemical Industries (Alderley Park, Cheshire), tobramycin was a gift from Eli Lilly (Basingstoke, Hampshire), sissomicin and netilmicin were gifts from Schering-Plough (Bloomfield, NJ, USA).

Bacteriophage typing was performed as described by Cafferkey et al. (1983).

Culture media. Bacteria were grown at $37^{\circ}$ for $18 \mathrm{~h}$ in 2-ml volumes of LB broth (Miller, 1972) or Trypticase Soy Broth (BBL, Cockeysville, MD, USA) on an orbital shaker set at $150 \mathrm{rpm}$. The corresponding agar media were also used. 1983).

Screening for plasmid DNA. Isolates were screened as previously described (Dowd et al.,

Antibiotic susceptibility tests were performed by a disk diffusion method. The sensitive control S. aureus strain RN4220 Nov was tested on a separate plate. Cultures were diluted 1 in $10^{3}$ in sterile saline and spread on DST Agar (Oxoid) plates. Disks containing the following antibiotics and other inhibitors were placed on the plates: benzylpenicillin 2 units; tetracycline 10 $\mu \mathrm{g}$; gentamicin $10 \mu \mathrm{g}$ : amikacin $30 \mu \mathrm{g}$; neomycin $20 \mu \mathrm{g}$; kanamycin $20 \mu \mathrm{g}$; fusidic acid $20 \mu \mathrm{g}$; streptomycin $50 \mu \mathrm{g}$; spectinomycin $50 \mu \mathrm{g}$; vancomycin $30 \mu \mathrm{g}$; erythromycin $15 \mu \mathrm{g}$; trimethoprim $2 \mu \mathrm{g}$; tobramycin $10 \mu \mathrm{g} ; \mathrm{HgCl}_{2} 10 \mu \mathrm{g} ; \mathrm{CdNO}_{3} 10^{-6}$ mols; ethidium bromide $20 \mu \mathrm{g}$. Results were read after incubation for $18 \mathrm{~h}$ at $37^{\circ} \mathrm{C}$. Tests for methicillin resistance were performed at $30^{\circ} \mathrm{C}$ with $10-\mu \mathrm{g}$ methicillin strips (Mast).

Minimum inhibitory concentration (MIC) determinations. Stationary-phase broth cultures were diluted 1 in $10^{4}$ and $c .0 .01 \mathrm{ml}\left(c .10^{3} \mathrm{cfu}\right)$ was applied to the surface of DST (aminoglycosides) or LB (cetrimide, chlorhexidine and dyes) plates containing concentrations of inhibitors in the range $0 \cdot 1-1 \cdot 0 \mu \mathrm{g} / \mathrm{ml}(0 \cdot 1 \mu \mathrm{g} / \mathrm{ml}$ intervals $), 1 \cdot 0-10 \cdot 0 \mu \mathrm{g} / \mathrm{ml}(1 \cdot 0 \mu \mathrm{g} / \mathrm{ml}$ intervals $)$, $10-100 \mu \mathrm{g} / \mathrm{ml}(10 \mu \mathrm{g} / \mathrm{ml}$ intervals $), 100-1000 \mu \mathrm{g} / \mathrm{ml}(100 \mu \mathrm{g} / \mathrm{ml}$ intervals $)$ or $1000-5000 \mu \mathrm{g} / \mathrm{ml}$ $(1000 \mu \mathrm{g} / \mathrm{ml}$ intervals).

Transformation. Protoplasts of S. aureus RN4220 Nov were prepared as described by Dowd et al. (1983) for use as recipients (Chang and Cohen, 1979). Plasmid DNA was prepared by the small scale method used for plasmid screening with the following additional steps: the DNA solution was extracted with aqueous phenol and precipitated with ethanol. Transformants were selected on DM3 agar plates (Chang and Cohen, 1979) containing tetracycline $(10 \mu \mathrm{g} / \mathrm{ml})$ or ethidium bromide $(20 \mu \mathrm{g} / \mathrm{ml})$.

Plasmid elimination experiments. Approximately $5 \times 10^{2}$ cells were inoculated into $2 \mathrm{ml}$ of LB broth and grown for $18 \mathrm{~h}$ at $42^{\circ} \mathrm{C}$. The cultures were diluted and spread on LB agar plates. Colonies were replica plated on agar containing tetracycline $10 \mu \mathrm{g} / \mathrm{ml}$ or $\mathrm{CdNO}_{3} 0.1 \mathrm{~mm}$. Putative cured colonies were purified from the master plate, examined for resistance markers and screened for the presence of plasmid DNA.

Isolation of plasmid DNA. Plasmid DNA for restriction endonuclease analysis was isolated from transformants of $S$. aureus RN4220 Nov harbouring plasmids from strains of MGRSA 
and MRSA as follows: cultures were grown in $500 \mathrm{ml}$ of LB broth in 2-L flasks shaken at $200 \mathrm{rpm}$ for $18 \mathrm{~h}$ at $37^{\circ} \mathrm{C}$. Cells were harvested by centrifugation at $8000 \mathrm{~g}$ for $10 \mathrm{~min}$, washed once in 20 $\mathrm{ml}$ of $10 \mathrm{~mm}$ ethylenediaminetetra-acetic acid (EDTA) at $p \mathrm{H} 8.0$ and resuspended in $10 \mathrm{ml}$ of 10 mM EDTA $(p \mathrm{H} \mathrm{8.0);48} \mathrm{ml}$ of an acetone-ethanol mixture (1:1) was then added. After incubation in an ice bath for $20 \mathrm{~min}, 120 \mathrm{ml}$ of $10 \mathrm{~mm}$ EDTA $p \mathrm{H} 8.0$ was added and incubation in ice was continued for a further $20 \mathrm{~min}$. Cells were centrifuged and resuspended in $20 \mathrm{ml}$ of buffer $(150$ $\mathrm{mm} \mathrm{NaCl}, 50 \mathrm{~mm}$ EDTA; $p \mathrm{H} \mathrm{8.0)} ; 250 \mu \mathrm{l}$ of lysostaphin (Sigma) $1 \mathrm{mg} / \mathrm{ml}$ in $50 \mathrm{~mm}$ trishydroxymethylaminomethane (Tris- $\mathrm{HCl})\left(p \mathrm{H} \mathrm{7.5)}\right.$ was then added. After incubation at $37^{\circ} \mathrm{C}$ for 20 min with gentle shaking, $2.8 \mathrm{ml}$ of $\mathrm{NaCl}(5.0 \mathrm{M}), 1.8 \mathrm{ml}$ of EDTA $(0.5 \mathrm{M} ; p \mathrm{H} 8.0)$ and 19.0 $\mathrm{ml}$ of sodium dodecyl sulphate (SDS) $2 \% \mathrm{w} / \mathrm{v}$ in $0.7 \mathrm{M} \mathrm{NaCl}$ was added and incubation was continued in ice for a further $18 \mathrm{~h}$ to lyse the cells. Chromosomal DNA and cell debris were then removed by centrifugation at $36000 \mathrm{~g}$ for $45 \mathrm{~min}$. The supernate was decanted into a $250-\mathrm{ml}$ Sorvall centrifuge bucket (Du Pont, Newtown, CT, USA). Pancreatic RNAase (Sigma) and T1 RNAase (Sigma) were added to a concentration of $100 \mu \mathrm{g} / \mathrm{ml}$. After incubation at $37^{\circ} \mathrm{C}$ for 30 min with gentle shaking, proteinase $\mathrm{K}$ (The Boehringer Corporation Ltd, Dublin, Ireland) was added to achieve a concentration of $50 \mu \mathrm{g} / \mathrm{ml}$; the tubes were incubated at $37^{\circ} \mathrm{C}$ for $30 \mathrm{~min}$. An equal volume of $1 \mathrm{M} \mathrm{NaCl}$ and polyethylene glycol 6000 (PEG) (Sigma) $10 \% \mathrm{w} / \mathrm{v}$ was added; the PEG was dissolved by gentle shaking and the tubes were incubated at $4 \mathrm{C}$ for $2 \mathrm{~h}$ to precipitate the plasmid DNA. The precipitate was recovered by centrifugation at $2000 \mathrm{~g}$ for $10 \mathrm{~min}$ at $10^{\circ} \mathrm{C}$ and resuspended in $8 \mathrm{ml}$ of $50 \mathrm{~mm}$ Tris- $\mathrm{HCl}(p \mathrm{H} \mathrm{7.5}) 10 \mathrm{~mm}$ EDTA $(p \mathrm{H} 8 \cdot 0) ; 7 \cdot 4 \mathrm{~g}$ of CsCl and 250 $\mu \mathrm{l}$ of ethidium bromide $(10 \mathrm{mg} / \mathrm{ml})$ were added and the plasmid DNA was purified by centrifugation in the 70.1 Ti rotor of a Beckman L8-55 ultracentrifuge (Beckman Instruments, Inc., CA, USA) for $40 \mathrm{~h}$ at $42000 \mathrm{rpm}$, at $18^{\circ} \mathrm{C}$.

Restriction enzymes and electrophoresis. Restriction enzymes (Boehringer) were used according to the manufacturer's instructions. DNA was fractionated in $1.0 \%$ agarose gels as described by Aaij and Borst (1972). Fragments of DNA generated by cleavage of bacteriophage lambda with the restriction enzymes EcoR 1 and BamH 1 (Daniels and Blattner, 1982) were used as mol. wt reference markers on agarose gels.

\section{RESULTS}

\section{Classification of MGRSA strains}

A total of 350 MGRSA strains, isolated from Dublin hospitals between July 1976 and March 1984, were examined. Another 20 MRSA strains isolated between 1970 and 1975 were included to determine whether similar resistance determinants and plasmids were present before the emergence of gentamicin resistance in 1976.

The MGRSA strains were divided into two groups according to their plasmid content and susceptibility to antibiotics and metal ions (table I). Phenotype-I strains were highly resistant to gentamicin, moderately resistant to amikacin and susceptible to fusidic acid. Those that were tetracycline resistant carried a $3.0 \times 10^{6}-\mathrm{mol}$. wt plasmid. Most strains assigned to phenotype II expressed a low level of resistance to gentamicin and were resistant to fusidic acid. Many carried a plasmid of $(22-24) \times 10^{6}$ mol. wt which could confer resistance to ethidium bromide, tetracycline, kanamycin and neomycin.

\section{Phage types}

Most MGRSA strains isolated during 1976 and early 1977 were of phage type $77 / 84$ or 77 . In 1976 , all isolates of these phage types belonged to phenotype I, but since then strains of both phenotypes have been isolated. Phage type- 85 strains were less 
TABLE I

Classification of methicillin- and gentamicin-resistant strains of S. aureus into two groups and properties of methicillin-resistant strains

\begin{tabular}{|c|c|c|c|c|c|}
\hline \multirow[b]{2}{*}{ Phenotype } & \multirow{2}{*}{$\begin{array}{l}\text { Number } \\
\text { of strains } \\
\text { tested }\end{array}$} & \multicolumn{2}{|c|}{$\begin{array}{l}\text { Location of resistance } \\
\text { determinants }\end{array}$} & \multirow{2}{*}{$\begin{array}{l}\text { Number of strains } \\
\text { carrying } \\
\text { plasmid* }\end{array}$} & \multirow{2}{*}{$\begin{array}{l}\text { Plasmid } \\
\text { mol. } \\
\text { wt }\left(10^{6}\right)\end{array}$} \\
\hline & & Chromosome & Plasmid & & \\
\hline I & 18 & $\begin{array}{l}\mathrm{Gm}^{\mathrm{H}} \mathrm{Ak} \mathrm{Ka} \mathrm{Me} \\
\mathrm{Sm} \text { Sp Em }\end{array}$ & $\begin{array}{l}\mathrm{Pc} \mathrm{Cd} \mathrm{Hg} \mathrm{Eb} \\
\mathrm{Tc}\end{array}$ & $\begin{array}{r}18 \\
7\end{array}$ & $\begin{array}{r}21 \cdot 0 \\
3 \cdot 0\end{array}$ \\
\hline \multirow[t]{2}{*}{ II } & 325 & $\begin{array}{l}\mathrm{Gm}^{\mathrm{L}} \mathrm{Ka} \mathrm{Me} \mathrm{Sm} \mathrm{Sp} \\
\mathrm{Em} \mathrm{Fu}\end{array}$ & $\mathrm{Pc} \mathrm{Cd} \mathrm{Hg} \mathrm{Eb}$ & 146 & $21 \cdot 0$ \\
\hline & & & $\begin{array}{l}\text { Tc Ka Ne Eb Tp } \\
\text { Tc Ka Ne Eb } \\
\text { Tc Tp Eb } \\
\text { Tc Eb } \\
\text { Ka Ne Eb }\end{array}$ & $\begin{array}{r}32 \\
15 \\
1 \\
6 \\
5\end{array}$ & $\begin{array}{l}22-24 \\
22-24 \\
22-24 \\
22-24 \\
22-24\end{array}$ \\
\hline MRSA & 20 & $\mathrm{Me} \mathrm{Sm} \mathrm{Sp} \mathrm{Em}$ & $\begin{array}{l}\mathrm{Pc} \mathrm{Cd} \mathrm{Hg} \mathrm{Eb} \\
\mathrm{Tc} \\
\mathrm{Tc} \mathrm{Ka} \mathrm{Ne} \mathrm{Eb} \\
\mathrm{Ka} \mathrm{Ne} \mathrm{Eb}\end{array}$ & $\begin{array}{r}20 \\
7 \\
5 \\
1\end{array}$ & $\begin{array}{c}21 \cdot 0 \\
3.0 \\
22-24 \\
22-24\end{array}$ \\
\hline
\end{tabular}

$\mathrm{Gm}^{\mathrm{H}}$, high level resistance to gentamicin $(>100 \mu \mathrm{g} / \mathrm{ml}) ; \mathrm{Gm}^{\mathrm{L}}$, low level resistance to gentamicin $(\leq 30$ $\mu \mathrm{g} / \mathrm{ml}$ ); Me, methicillin; Sm, streptomycin; Sp, spectinomycin; Ak, amikacin; Ka, kanamycin; Em, erythromycin; Pc, penicillin; Cd, cadium ions, $\mathrm{Hg}$, mercuric ions; $\mathrm{Eb}$, ethidium bromide; Tc, tetracycline; $\mathrm{Fu}$, fusidic acid; Tp, trimethroprim; Ne, neomycin

* All phenotype-I and MRSA strains and 146 of the 325 phenotype-II strains were screened.

common, although they predominated during the second half of 1977 and in 1978; all of these were of phenotype I. Since 1978, most strains have been of phenotype II and were untypable with the standard phage set. Strains with a broad phage-sensitivity pattern have been encountered regularly since 1980. These include phage types $6 / 47 / 54 / 85$ and $6 / 47 / 54 / 77 / 84 / 85$; all were of phenotype II. No phenotype-I strains have been isolated since 1982 .

All the MRSA strains were of phage type 77 or $77 / 84$ except for two isolates, one of which was of type $47 / 54 / 75 / 77 / 85$ and the other of type $47 / 54 / 75 / 77 / 84 / 85$.

\section{Resistance to antimicrobial agents}

All the MGRSA and MRSA strains were resistant to penicillin, erythromycin, methicillin, streptomycin, spectinomycin, mercuric ions, cadmium ions and ethidium bromide. They were all susceptible to arsenate and vancomycin. All MGRSA strains were resistant to gentamicin and kanamycin (table II).

\section{Plasmid screening experiments}

All MRSA strains and phenotype-I MGRSA strains and 146 of 350 phenotype-II MGRSA isolates were screened for plasmids. All harboured a $21 \times 10^{6}-\mathrm{mol}$. wt plasmid. Seven of the 18 phenotype-I strains were resistant to tetracycline and carried a $3.0 \times 10^{6}$-mol. wt plasmid. A $3.0 \times 10^{6}-\mathrm{mol}$. wt plasmid was also observed in seven of 12 tetracycline resistant MRSA strains.

Of the 146 phenotype-II strains tested, 59 harboured another plasmid in the size range $(22-24) \times 10^{6} \mathrm{~mol}$. wt. The presence of this type of plasmid correlated with 
TABLE II

Susceptibility to antimicrobial agents of MGRSA and MRSA isolates

\begin{tabular}{lcc}
\hline & \multicolumn{2}{c}{$\begin{array}{c}\text { Percentage of } \\
\text { strains resistant }\end{array}$} \\
\cline { 2 - 3 } Antimicrobial & $\begin{array}{c}\text { MGRSA } \\
\text { agent }\end{array}$ & $\begin{array}{c}\text { MRSA } \\
(350)\end{array}$ \\
\hline Methicillin & 100 & 100 \\
Streptomycin & 100 & 100 \\
Spectinomycin & 100 & 100 \\
Gentamicin & 100 & 0 \\
Kanamycin & 100 & 25 \\
Neomycin & 34 & 25 \\
Amikacin & $100^{*}$ & 0 \\
Penicillin G & 100 & 100 \\
Cadmium nitrate & 100 & 100 \\
Mercuric chloride & 100 & 100 \\
Ethidium bromide & 100 & 100 \\
Tetracycline & 44 & 60 \\
Trimethoprim $\dagger$ & 26 & 0 \\
Erythromycin & 100 & 10 \\
Fusidic acid & 95 & 0 \\
Vancomycin & 0 & 0 \\
\hline
\end{tabular}

* Includes phenotype II strains that were of reduced sensitivity to amikacin (MIC $2 \mu \mathrm{g} / \mathrm{ml}$ ). $\dagger$ Only 120 of the MGRSA strains were tested against trimethoprim.

various patterns of resistance as shown in table I. A similar plasmid was found in six of 20 MRSA strains and its presence correlated with expression of resistance to neomycin, kanamycin and ethidium bromide.

\section{Plasmid elimination}

Representative strains from the two phenotypes of MGRSA were grown at $42^{\circ} \mathrm{C}$ to promote plasmid loss. Up to half of the cells of tetracycline-resistant strains of both phenotypes were tetracycline sensitive after growth at $42^{\circ} \mathrm{C}$. Plasmid-screening experiments revealed that a $3 \times 10^{6}$-mol. wt element was eliminated from tetracyclineresistant strains of phenotype I, whereas a $24 \times 10^{6}-\mathrm{mol}$. wt element was lost from tetracycline-resistant strains of phenotype II. Phenotype-II strains that were resistant to neomycin or trimethoprim also lost these markers.

The $21 \times 10^{6}$-mol. wt plasmid was eliminated from only one strain of each group. In both cases resistance to cadmium, mercury, penicillin and ethidium bromide were lost concomitantly. Plasmid-free variants still expressed resistance to methicillin, gentamicin, kanamycin, erythromycin, streptomycin and spectinomycin; phenotype-II strains were also resistant to fusidic acid.

\section{Plasmid transfer}

DNA from tetracycline-resistant phenotype-I strains yielded tetracycline-resistant transformants of $S$. aureus RN4220 Nov at a high frequency. Screening tests showed that a $3 \times 10^{6}$-mol. wt plasmid had been transferred.

When resistance to ethidium bromide was selected, a lower frequency of 
transformation was obtained. In each case the transformants had also acquired resistance to cadmium, mercury and penicillin associated with a $21 \times 10^{6}$-mol. wt plasmid.

DNA from phenotype-II strains was used to transform S. aureus RN4220 Nov with selection for resistance to tetracycline or ethidium bromide. Two classes of ethidium bromide-resistant transformants were obtained: those in which resistance to cadmium, penicillin and mercury was linked on a $21 \times 10^{6}$-mol. wt plasmid; and those that had also acquired resistance to kanamycin, neomycin, trimethoprim and tetracycline on a $(22-24) \times 10^{6}$-mol. wt plasmid. Similar experiments with MRSA strains revealed that resistance to ethidium bromide was associated with a $21 \times 10^{6}-\mathrm{mol}$. wt plasmid carrying cadmium, penicillin and mercury resistance, and, in some cases, with a large plasmid carrying kanamycin, neomycin and tetracycline resistance similar to those found in phenotype-II MRSA strains. In some tetracycline-resistant strains, a $3 \times 10^{6}$-mol. wt. plasmid was transferred.

Resistance to ethidium bromide, cetrimide, chlorhexidine, and dyes

All MGRSA were resistant to ethidium bromide (table II). To examine the involvement of plasmids in this phenotype, strain SA20 (phenotype II) was cured of plasmids conferring resistence to tetracycline and penicillin. It was not possible to obtain a penicillin-sensitive, tetracycline-resistant variant.

The penicillin-resistant, tetracycline-sensitive strain retained resistance to ethidium bromide, whereas the strain that was sensitive to penicillin and tetracycline was also susceptible to the inhibitor. $S$. aureus strain RN4220 carrying a $21 \times 10^{6}$-mol. wt plasmid specifying penicillin resistance (pPC128) or a $24 \times 10^{6}-\mathrm{mol}$. wt plasmid specifying tetracycline resistance (pTC128) was shown to be resistant to ethidium bromide. Thus, both plasmids in the phenotype-II strain SA128 conferred resistance to ethidium bromide. These findings were confirmed by transforming $S$. aureus RN4220 Nov with plasmids that specified penicillin and tetracycline resistance from several other strains.

Ethidium bromide resistance was also associated with resistance to cetyltrimethyl ammonium bromide (cetrimide), chlorhexidine, acriflavine and gentian violet (table III). The presence of two copies of the ethidium bromide-resistance marker in strain SA20 did not cause an increase in resistance over that of strains carrying a single copy.

TABLE III

Minimum inhibitory concentrations of chlorhexidine, cetrimide and dyes

\begin{tabular}{l|ccccc}
\hline & \multicolumn{4}{|c}{ Minimum inhibitory concentration $(\mu \mathrm{g} / \mathrm{ml})$ of } \\
\cline { 2 - 6 } $\begin{array}{l}S . \text { aureus } \\
\text { strain }\end{array}$ & $\begin{array}{c}\text { Ethidium } \\
\text { bromide }\end{array}$ & $\begin{array}{c}\text { Cetyltrimethyl } \\
\text { ammonium bromide }\end{array}$ & $\begin{array}{c}\text { Chlorhexidine } \\
\text { Acriflavine }\end{array}$ & $\begin{array}{c}\text { Gentian } \\
\text { violet }\end{array}$ \\
\hline RN4220 & 0.75 & $0 \cdot 5$ & 0.25 & 20 & 0.075 \\
RN4220 (pPC128) & 170 & 2.0 & 0.75 & 250 & 0.25 \\
RN4220 (pTC128) & 170 & $2 \cdot 0$ & 0.75 & 250 & 0.25 \\
SA20 (pPC20, pTC20) & 170 & $2 \cdot 0$ & 0.75 & 250 & 0.75 \\
SA20Tcs (pPC20) & 170 & $2 \cdot 0$ & 0.75 & 250 & 0.75 \\
SA20Tcs Pc & 0.75 & 0.5 & 0.25 & 30 & 0.1 \\
\hline
\end{tabular}




\section{Resistance to aminoglycosides}

The MICs of several aminoglycosides for phenotype-I and -II MGRSA strains are shown in table IV. Derivatives which were cured of plasmids and transformants of strain RN4200 Nov carrying individual plasmids from these strains were also tested.

Phenotype-I strains were more resistant to all the aminoglycosides (except neomycin and kanamycin) than were most phenotype-II strains. Loss of the $3 \times 10^{6}-\mathrm{mol}$. wt or the $21 \times 10^{6}-\mathrm{mol}$. wt plasmid did not affect resistance.

The phenotype-II strains that harboured a $(22-24) \times 10^{6}-\mathrm{mol}$. wt plasmid were, like phenotype-I strains, highly resistant to kanamycin (MIC $1000 \mu \mathrm{g} / \mathrm{ml}$ ); they were also resistant to neomycin. Strains lacking this plasmid, including those from which the plasmid had been eliminated, were susceptible to neomycin and were less resistant to kanamycin (MIC $100 \mu \mathrm{g} / \mathrm{ml}$ ). Furthermore, transformants of $S$. aureus RN4220 carrying this plasmid expressed resistance to kanamycin (MIC $200 \mu \mathrm{g} / \mathrm{ml}$ ) and to neomycin.

Eight of 338 phenotype-II strains were more resistant to gentamicin, amikacin, tobramycin, sisomicin and neomycin than the rest. Three levels of resistance to gentamicin were detected: three strains were inhibited by $80-100 \mu \mathrm{g} / \mathrm{ml}$, three strains by $250-300 \mu \mathrm{g} / \mathrm{ml}$ and two strains by $1500-1600 \mu \mathrm{g} / \mathrm{ml}$.

The MRSA strains that carried a $(22-24) \times 10^{6}-\mathrm{mol}$. wt plasmid similar to the phenotype-II MGRSA strains were resistant to kanamycin and neomycin.

\section{Restriction endonuclease analysis of plasmid DNA}

Plasmid DNA was purified from ethidium bromide- and tetracycline-resistant transformants of $S$. aureus RN4220 Nov habouring plasmids from representative

TABLE IV

Minimum inhibitory concentrations of aminoglycosides for MGRSA and MRSA strains

\begin{tabular}{|c|c|c|c|c|c|c|c|c|}
\hline \multirow{2}{*}{$\begin{array}{l}\text { S. aureus } \\
\text { strain }\end{array}$} & \multirow[b]{2}{*}{ Phenotype } & \multicolumn{7}{|c|}{ Minimum inhibitory concentrations $(\mu \mathrm{g} / \mathrm{ml})$ of } \\
\hline & & $\mathrm{Ak}$ & $\mathrm{Gm}$ & $\mathrm{Ka}$ & $\mathrm{Ne}$ & $\mathbf{S i}$ & To & $\mathrm{Nt}$ \\
\hline $\begin{array}{l}\text { SA614 } \mathrm{Tc}^{\mathrm{r}} \mathrm{Pc}^{\mathrm{r}} \\
\text { SA614 } \mathrm{Tc}^{\mathrm{s}} \mathrm{Pc}^{\mathrm{r}} \\
\text { SA614 } \mathrm{Tc}^{\mathrm{s}} \mathrm{Pc}^{\mathrm{s}} \\
\text { SA128 } \mathrm{Tc}^{\mathrm{r}} \mathrm{Pc}^{\mathrm{r}} \\
\text { SA128 } \mathrm{Tc}^{\mathrm{s}} \mathrm{Pc}^{\mathrm{r}} \\
\text { RN4220 } \\
\text { RN4220 (pPC128)* } \\
\text { RN4220 (pTC128)* } \\
\text { SA229 } \\
\text { SA49 } \\
\text { SA724 } \\
\text { SA150 Ne } \\
\text { RN4220 (pNE150) }\end{array}$ & $\begin{array}{l}\text { Atypical II } \\
\text { Atypical II } \\
\text { Atypical II } \\
\text { MRSA }\end{array}$ & $\begin{array}{c}10 \\
10 \\
10 \\
2 \\
2 \\
0 \cdot 6 \\
0 \cdot 6 \\
0 \cdot 6 \\
40 \\
6 \\
15 \\
0 \cdot 6 \\
0 \cdot 4\end{array}$ & $\begin{array}{c}200 \\
200 \\
200 \\
20 \\
20 \\
0 \cdot 3 \\
0 \cdot 3 \\
0 \cdot 2 \\
1600 \\
100 \\
300 \\
0 \cdot 2 \\
0 \cdot 2\end{array}$ & $\begin{array}{r}1000 \\
1000 \\
1000 \\
1000 \\
100 \\
<1 \\
<1 \\
200 \\
5000 \\
2000 \\
3500 \\
200 \\
200\end{array}$ & $\begin{array}{l}<1 \\
<1 \\
<1 \\
30 \\
<1 \\
<1 \\
<1 \\
20 \\
20 \\
20 \\
20 \\
10 \\
10\end{array}$ & $\begin{array}{c}30 \\
30 \\
30 \\
0 \cdot 8 \\
0 \cdot 8 \\
0 \cdot 2 \\
0 \cdot 2 \\
0 \cdot 2 \\
100 \\
10 \\
50 \\
0 \cdot 2 \\
0 \cdot 2\end{array}$ & $\begin{array}{c}80 \\
80 \\
80 \\
10 \\
10 \\
0 \cdot 2 \\
0 \cdot 2 \\
0 \cdot 2 \\
200 \\
50 \\
120 \\
0 \cdot 2 \\
0 \cdot 2\end{array}$ & $\begin{array}{c}20 \\
20 \\
20 \\
2 \\
2 \\
0 \cdot 2 \\
0 \cdot 2 \\
0 \cdot 2 \\
110 \\
10 \\
40 \\
0 \cdot 2 \\
0 \cdot 2\end{array}$ \\
\hline
\end{tabular}

Ak, amikacin; Gm, gentamicin; Ka, kanamycin; Ne, neomycin; Si, sissomicin; To, tobramycin; Nt, netilmicin.

* Plasmid pPC128 was the $21 \times 10^{6}$-mol. wt plasmid from $S$. aureus strain SA128; pTC128 was the $(22-24) \times 10^{6}-\mathrm{mol}$. wt plasmid from the same isolate.

$\dagger$ Plasmid pNE150 was the $(22-24) \times 10^{6}-$ mol. wt plasmid from the MRSA strain SA150. 

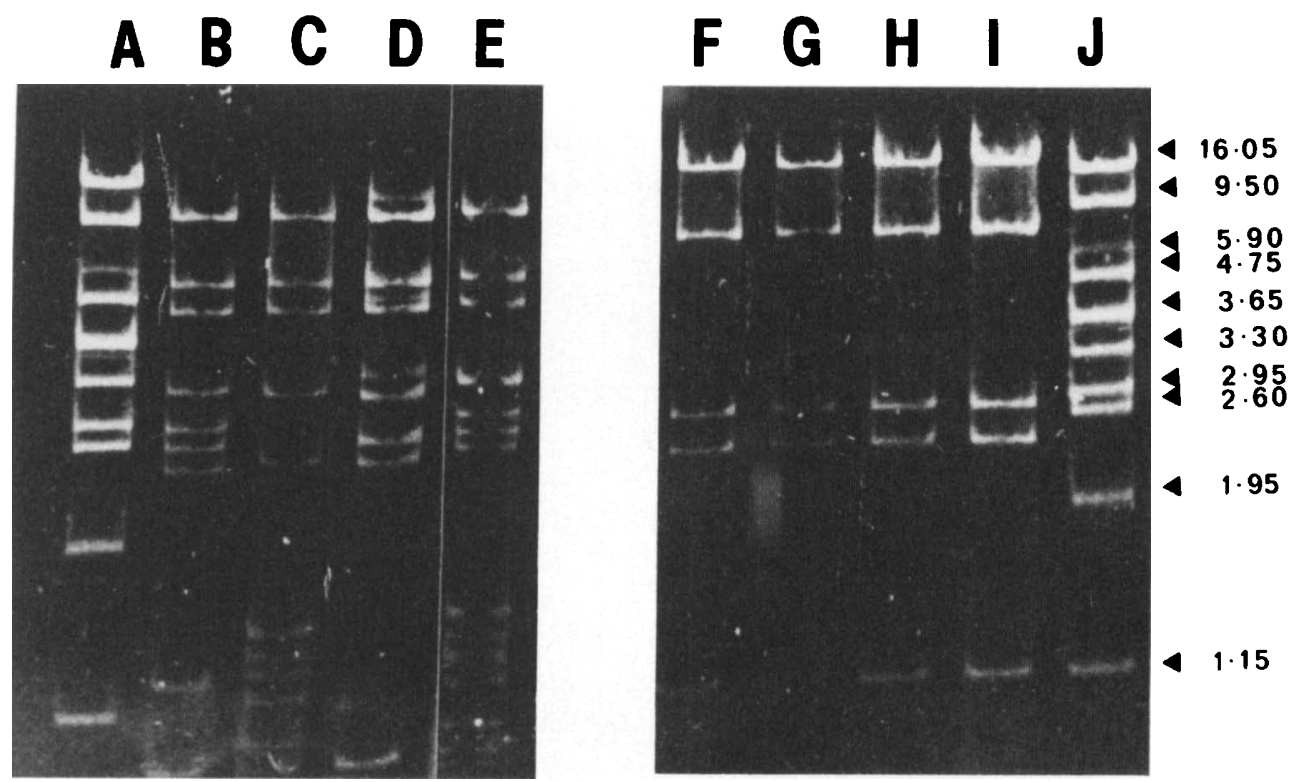

FIG.-Agarose gel electrophoresis of purified $S$. aureus plasmid DNA cleaved with restriction enzymes. Lanes A and J contain DNA fragments of bacteriophage lambda cleaved by both EcoRI and BamHI, as mol. wt reference markers. Fragment sizes (in $\mathrm{kb}$ ) are shown on the right. (Lanes B-E: $(22-24) \times 10^{6}$-mol. wt plasmids from MRSA (lane B) and phenotype-II MGRSA strains (lanes C, D and E) cleaved with Hind III. Lanes F-I: $21 \times 10^{6}$-mol. wt plasmids encoding resistance to penicillin, cadmium, mercury and ethidium bromide from phenotype-I MGRSA (lane F), phenotype-II MGRSA (lanes $\mathrm{G}$ and $\mathrm{H}$ ) and MRSA strains (lane I) cleaved with $E c o$ RI. The resistance determinants encoded by the $(22-24) \times 10^{6}$ plasmids were: lane B: ethidium bromide, kanamycin, neomycin; lane $\mathrm{C}$ : ethidium bromide, tetracycline, trimethoprim; lanes $\mathrm{D}$ and $\mathrm{E}$ : ethidium bromide, kanamycin, neomycin, tetracycline and trimethoprim.

MRSA and MGRSA strains and was cleaved by the restriction enzymes EcoRI and Hind III. Agarose gel electrophoresis showed that fragment patterns of all the plasmids conferring penicillin resistance were identical (fig., lanes F-I; Hind III data not shown). Cleavage by $H$ ind III of the $(22-24) \times 10^{6}-\mathrm{mol}$. wt plasmids harboured by some MRSA and phenotype-II MGRSA strains revealed that the plasmids had several fragments in common but some differences were also observed (fig. lanes B-E).

\section{Discussion}

The MGRSA strains described here were divided into two groups based on plasmid profiles and resistance determinants. The strains had several features in common with the MRSA strains isolated in Dublin hospitals between 1970 and 1975: they all expressed chromosomal resistance to methicillin, erythromycin, spectinomycin and streptomycin and carried a $21 \times 10^{6}-\mathrm{mol}$. wt plasmid conferring resistance to penicillin, cadmium, mercury and ethidium bromide. Furthermore, restriction enzyme analysis showed the penicillinase plasmids, as well as the $(22-24) \times 10^{6}-\mathrm{mol}$. wt plasmid found in MRSA and phenotype-II MGRSA strains, to be closely related. Differences observed could be partly due to variations in resistance determinants.

It seems likely that the MRSA strains encountered earlier acquired gentamicin resistance by gene transfer events which resulted in the determinant being incorporated 
in the chromosome, possibly by transposition (Lyon et al., 1984b). The relationship between phenotype-I and -II MGRSA strains is being investigated.

The MGRSA strains isolated in Dublin differ from similar $S$. aureus strains that have been reported from France, Australia, the UK and the USA (Soussy et al., 1975; Shanson et al., 1976; Crossley et al., 1979; McGowan et al., 1979; Price et al., 1980; Jaffe et al., 1982; Archer and Mayhall, 1983; Lyon et al., 1983; Naidoo et al., 1983; Townsend et al., 1983a) by invariably exhibiting chromosomal resistance to gentamicin. In strains reported from the USA, resistance to gentamicin is often encoded by large conjugative plasmids (Archer and Johnston, 1983; Forbes and Schaberg, 1983; McDonnell et al., 1983). Plasmid and chromosomal resistance has been found in Australian strains (Gillespie et al., 1984; Lyon et al., 1983 and 1984a; Townsend et al., $1983 a$ and $1984 a$ ), the variable location possibly being due to a transposon (Lyon et al., 1984b; Townsend et al., 1984a). The Australian strains also differ from those reported here by exhibiting chromosomal resistance to penicillin (Lyon et al., 1983; Townsend et al., 1983a; Gillespie et al., 1984). Chromosomal resistance to penicillin is unusual in European and American isolates.

Plasmid-mediated resistance to tetracycline in $S$. aureus is usually conferred by a $3 \times 10^{6}$-mol. wt plasmid (Lacey, 1975 and 1984) such as that detected in our phenotype-I MGRSA strains and in some American and Australian isolates (McDonnell et al., 1983; Gillespie et al., 1984). Resistance to tetracycline specified by large plasmids such as those found in our phenotype- II strains have been reported previously in $S$. aureus in strains from France that were also resistant to streptogramin B antibiotics (El Solh et al., 1980).

Another unusual feature of the MGRSA strains described here was the occurrence of plasmid-borne resistance to trimethoprim. This resistance marker is usually chromosomal in S. aureus (Lewis and Lacey, 1973; Lacey, 1975) although such plasmids have been found in MGRSA strains in Australia (Townsend et al., 1984a). Furthermore, in Australian strains, tetracycline resistance was usually chromosomal (Gillespie et al., 1984).

The pattern of aminoglycoside resistance displayed by strains from Dublin that were highly resistant to gentamicin suggests the involvement of $\mathrm{APH}\left(2^{\prime \prime}\right)$ and $\mathrm{AAC}\left(6^{\prime}\right)$, enzymes previously shown to be responsible for gentamicin resistance in $S$. aureus (Phillips and Shannon, 1984). Resistance to kanamycin and neomycin specified by the $(22-24) \times 10^{6}-\mathrm{mol}$. wt plasmid is most likely due to APH(3') (Phillips and Shannon, 1984).

Plasmid-mediated resistance to ethidium bromide in $S$. aureus, first reported by Johnston and Dyke (1969), is common in MGRSA strains (Jaffe et al., 1982; Townsend et al., 1983b; Lyon et al., 1984b) and was present in all Dublin isolates. Resistance to quaternary ammonium compounds and to cationic surfactive agents specified by such plasmids was first reported by Townsend et al. (1983b and 1984b). It seems possible that resistance to these compounds, which are commonly used as antiseptics and disinfectants, is specified by the same, or closely linked, determinants.

We are indebted to the Medical Research Council of Ireland for a Hospital Infection Unit Programme grant. We thank Professor J. P. Arbuthnott, for his valuable guidance, Dr M. Storrs for performing antibiotic titrations, Dr Lesley Baxter for antibiograms, Miss Lindsay Jones for the strains, Mrs M. de Saxe of the Staphylococcal Reference Laboratory, Colindale, London, for typing phages and Gillian Johnston and Mairead Daly for help in preparing the manuscript. 


\section{REFERENCES}

Archer G L, Johnston J L 1983 Self-transmissible plasmids in staphylococci that encode resistance to aminoglycosides. Antimicrobial Agents and Chemotherapy 24:70-77.

Archer G L, Mayhall C G 1983 Comparison of epidemiological markers used in the investigation of an outbreak of methicillin-resistant Staphylococcus aureus infections. Journal of Clinical Microbiology 18:395-399.

Aaji C, Borst P 1972 The gel electrophoresis of DNA. Biochimica et Biophysica Acta 269: 192-200.

Cafferkey M T, Hone R, Falkiner F R, Keane C T, Pomeroy H 1983 Gentamicin and methicillin resistant Staphylococcus aureus in Dublin Hospitals: clinical and laboratory studies. Journal of Medical Microbiology 16:117-127.

Chang S, Cohen S N 1979 High frequency transformation of Bacillus subtilis protoplasts by plasmid DNA. Molecular and General Genetics 168:111-115.

Crossley K, Loesch D, Landesman B, Mead K, Chern M, Strate R 1979 An outbreak of infections caused by strains of Staphylococcus aureus resistant to methicillin and aminoglycosides. I. Clinical studies. Journal of Infectious Diseases 139: 273-279.

Daniels D L, Blattner F R 1982 Nucleotide sequence of the Q gene and the Q to S intergenic region of bacteriophage lambda. Virology 117:81-92.

Dowd D, Cafferkey M, Dougan G 1983 Gentamicin and methicillin resistant Staphylococcus aureus in Dublin hospitals: molecular studies. Journal of Medical Microbiology 16:129-138.

El Solh N, Fouace J M, Shalita Z, Bouanchaud D H, Novick R P, Chabbert Y A 1980 Epidemiological and structural studies of Staphylococcus aureus $\mathbf{R}$ plasmids mediating resistance to tobramycin and streptogramin. Plasmid 4:117-120.

Fairweather N, Kennedy S, Foster T J, Kehoe M, Dougan G 1983 Expression of a cloned Staphylococcus aureus $\alpha$-hemolysin determinant in Bacillus subtilis and Staphylococcus aureus. Infection and Immunity 41:1112-1117.

Forbes B A, Schaberg D R 1983 Transfer of resistance plasmids from Staphylococcus epidermidis to Staphylococcus aureus: Evidence for conjugative exchange of resistance. Journal of Bacteriology 153:627-634.

Gillespie M T, May J W, Skurray R A 1984 Antibiotic susceptibilities and plasmid profiles of nosocomial methicillin-resistant Staphylococcus aureus: A retrospective study. Journal of Medical Microbiology 17:295-310.

Hone R et al. 1981 Bacteraemia in Dublin due to gentamicin-resistant Staphylococcus aureus. Journal of Hospital Infection 2:119-126.

Jaffe H W, Sweeney H M, Weinstein R A, Kabins S A, Nathan C, Cohen S 1982 Structural and phenotypic varieties of gentamicin resistance plasmids in hospital strains of Staphylococcus aureus and coagulase-negative staphylococci. Antimicrobial Agents and Chemotherapy 21:773-779.

Johnston L H, Dyke K G H 1969 Ethidium bromide resistance, a new marker on the staphylococcal penicillinase plasmid. Journal of Bacteriology 100:1413-1414.

Kreiswirth B N et al. 1983 The toxic shock syndrome exotoxin structural gene is not detectably transmitted by a prophage. Nature 305:709-712.

Lacey R W 1975 Antibiotic resistance plasmids of Staphylococcus aureus and their clinical importance. Bacteriological Reviews 39:1-32.

Lacey R W 1984 Antibiotic resistance in Staphylococcus aureus and streptococci. British Medical Bulletin 40:77-83.

Lewis E L, Lacey R W 1973 Present significance of resistance to trimethoprim and sulphonamides in coliforms, Staphylococcus aureus, and Streptococcus faecalis. Journal of Clinical Pathology 26:175-180.

Lyon B R, May J W, Skurray R A 1983 Analysis of plasmids in nosocomial strains of multiple-antibiotic-resistant Staphylococcus aureus. Antimicrobial Agents and Chemotherapy 23:817-826.

Lyon B R, Iuorio J L, May J W, Skurray R A 1984a Molecular epidemiology of multiresistant Staphylococcus aureus in Australian hospitals. Journal of Medical Microbiology 17:79-89.

Lyon B R, May J W, Skurray R A 1984b Tn4001: A gentamicin and kanamycin resistance transposon in Staphylococcus aureus. Molecular and General Genetics 193:554-556. 
McDonnell R W, Sweeney H M, Cohen S 1983 Conjugational transfer of gentamicin resistance plasmids intra- and interspecifically in Staphylococcus aureus and Staphylococcus epidermidis. Antimicrobial Agents and Chemotherapy 23:151-160.

McGowan J E, Terry P M, Huang T-SR, Houk C L, Davies J 1979 Nosocomial infections with gentamicin-resistant Staphylococcus aureus: plasmid analysis as an epidemiologic tool. Journal of Infectious Diseases 140:864-872.

Miller J H 1972 Experiments in molecular genetics. Cold Spring Harbor Laboratory, Cold Spring Harbor, New York, p 433.

Naidoo J, Noble W C, Weissmann A, Dyke K G H 1983 Gentamicin-resistant staphylococci: genetics of an outbreak in a dermatology department. Journal of Hygiene 91:7-16.

Phillips I, Shannon K 1984 Aminoglycoside resistance. British Medical Bulletin 40:28-35.

Price E H, Brain A, Dickson J A 1980 An outbreak of infection with a gentamicin and methicillin-resistant Staphylococcus aureus in a neonatal unit. Journal of Hospital Infection 1:221-228.

Shanson D C, Kensit J G, Duke R 1976 Outbreak of hospital infection with a strain of Staphylococcus aureus resistant to gentamicin and methicillin.Lancet 2: 1347-1348.

Soussy C J, Bouanchaud D H, Fouace J. Dublanchet A, Duval J 1975 A gentamicin resistance plasmid in Staphylococcus aureus. Annales de Microbiologie (Paris) 126b:91-94.

Townsend D E, Grubb W B, Ashdown N 1983a Genetics of drug resistance in methicillin-resistant Staphylococcus aureus from Australian hospitals. Journal of Hospital Infection 4:331-337.

Townsend D E, Greed L, Ashdown N, Grubb W B $1983 b$ Plasmid-mediated resistance to quaternary ammonium compounds in methicillin-resistant Staphylococcus aureus. Medical Journal of Australia 2:310.

Townsend D E, Ashdown N, Greed L C, Grubb W B 1984a Analysis of plasmids mediating gentamicin resistance in methicillin-resistant Staphylococcus aureus. Journal of Antimicrobial Chemotherapy 13:347-352.

Townsend D E, Ashdown N, Greed L C, Grubb W B $1984 b$ Transposition of gentamicin resistance to staphylococcal plasmids encoding resistance to cationic agents. Journal of Antimicrobial Chemotherapy 14:115-124. 